Крикун П. М. ${ }^{1}$;

Павленко В. І. ${ }^{2}$;

Полякова О. В. ${ }^{2}$;

Кравчук В. В. ${ }^{3}$

1 - Національний інститут стратегічних досліджень, Київ;

2 - Центр воєнно-стратегічних досліджень Національного університету оборони України імені Івана Черняховського, Київ;

3 - Департамент воєнної політики, стратегічного планування та міжнародного співробітництва Міністерства оборони України, Київ

\title{
Розвиток оборонного планування як складової національної системи планування у сфері безпеки і оборони за умов наближення до процедур та стандартів НАТО
}

Резюме. Проведено аналіз стану та вимог до вітчизняної системи оборонного планування в умовах широкого спектра сучасних воєнних загроз та перспектив розвитку відповідно до принципів та стандартів HATO

Ключові слова: оборонне планування, воєнні загрози, воєнна безпека, оборона держави, сили оборони, оборонний огляд, стратегічне планування застосування сил оборони, бюджетне планування, спроможності сил оборони, Стратегія воєнної безпеки, цикли оборонного планування, стандарти НАТО.

Постановка проблеми. Широкий спектр сучасних воєнних загроз, необхідність перегляду широкого кола питань, пов'язаних 3 обороною держави, обумовлюють необхідність стратегічного перегляду концепції оборони 3 урахуванням досвіду подолання поточної кризи, запровадження нових методів керівництва обороною, які грунтуються на євроатлантичному та національному досвіді та відповідають критерію - висока ефективність за прийнятних витрат". При цьому створюється принципово нова функціональна структура сектор безпеки i оборони держави - як головний елемент системи забезпечення воєнної безпеки при визначальній ролі в цьому сил оборони.

Ці та інші фактори вимагають суттєвих змін щодо принципів, змісту і порядку оборонного планування, які викладені в Законі України "Про організацію оборонного планування".

Аналіз

основних досліджень і

публікацій. Незважаючи на значний вітчизняний досвід досліджень щодо визначення та реалізації оборонного планування, як свідчать результати оборонного огляду, залишається “недосконалість процедур оборонного планування, їх недостатня узгодженість 3 бюджетним процесом, недосконалість механізмів програмного управління оборонними ресурсами".

Недостатньо вивченими залишаються умови, які критично необхідні суб'єктам оборонного планування при усвідомленні та своєчасному вирішенні наступних управлінських завдань: уточнення воєннополітичних цілей i завдань та їх законодавче i нормативне оформлення; раціональний розподіл ресурсів, у першу чергу фінансових, для досягнення цих цілей та виконання відповідних завдань; створення ефективного механізму розподілу виділених ресурсів на оборону та контролю за їх використанням.

Системний аналіз цих та інших проблем обумовлює нагальну потребу у розробленні нового комплексу процедур оборонного планування, який забезпечив би: інтегрування спроможностей складових сектору безпеки i оборони для ефективного реагування на наявні та потенційні загрози; підвищення рівня координованості складових сектору безпеки i оборони та вдосконалення механізмів їх консолідованого розвитку i посилення відповідних оперативних спроможностей для забезпечення воєнної безпеки; досягнення оперативної і технічної сумісності зі збройними силами держав-членів НАТО; функціональний зв'язок зі стратегічним (оперативним) плануванням застосування сил оборони та бюджетним плануванням. 
Метою статті $\epsilon$ на основі аналізу досвіду вітчизняного оборонного планування надати свої погляди щодо перспективи його розвитку відповідно до принципів та стандартів НАТО.

Викладення основного матеріалу. Для визначення перспектив розвитку такого складного процесу, яким $€$ оборонне планування, необхідно перш за все чітко уяснити порядок визначення цілей оборонної реформи, зміст та логічну послідовність заходів планування.

Вихідною позицією цього процесу $\epsilon$ стратегічний оборонний огляд. Його повнота, якість підготовлених за його результатами звітних інформаційно-аналітичних матеріалів та чітке визначення перспектив розвитку об' єктів планування створює основу для ефективного оборонного планування.

Важливим підгрунтям для оборонного планування, що дозволяє досягти балансу між амбітними цілями оборонної реформи i ресурсними можливостями $\epsilon$ прогнозні показники видатків Державного бюджету України на потреби оборони у довгостроковій i середньостроковій перспективі. Вони дозволяють провести фінансово-економічні розрахунки заходів розвитку сил оборони, а також оцінити ризики у досягненні результатів оборонного планування.

3 урахуванням принципів і стандартів оборонного планування НАТО, для України в нинішніх умовах, найбільш прийнятним $\epsilon$ комплексне поєднання можливостей, механізмів і інструментарію оборонного планування - планування, основаного на спроможностях і загрозах. Одночасно 3 ними використовуються й інші специфічні методи планування - планування на основі ресурсів, поступове планування, планування основане на сценаріях.

Перспективний варіант структурнологічної схеми оборонного планування, яке поєднує згадані методи, представлений на рис. 1 .

Наведена схема відображає логічну послідовність основних процедур, включаючи прийняття рішення на проведення чергового циклу планування, елементи стратегічного (оперативного) планування застосування сил оборони та безпосереднє оборонне планування у взаємозв'язку з бюджетним плануванням. Результати оборонного планування викладаються в основних документах, відображених на схемі.

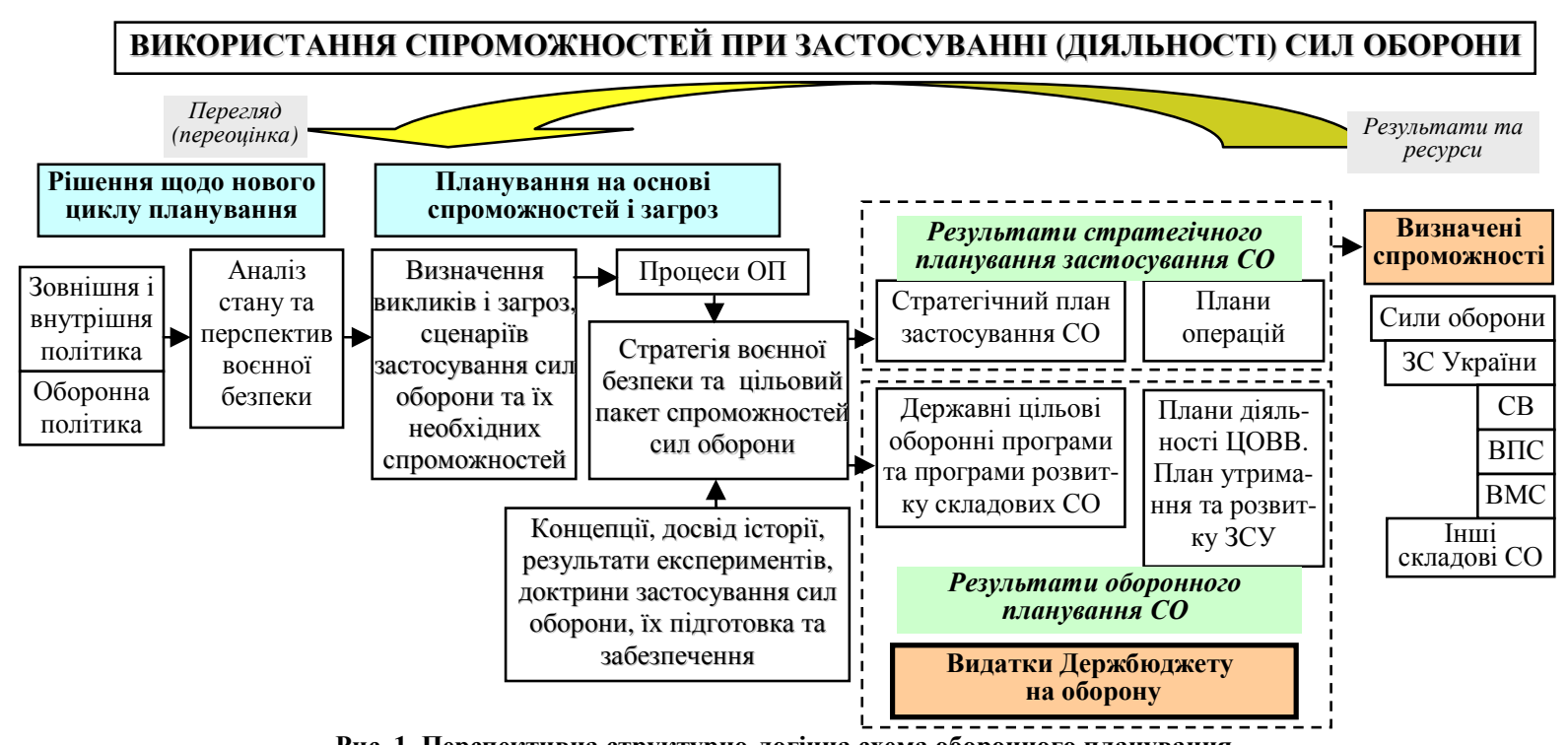

Рис. 1. Перспективна структурно-логічна схема оборонного планування

Особливого значення при стратегічному (оперативному) i оборонному плануванні надається прогнозу воєнно-політичної i воєнно-стратегічної обстановки, тенденцій їх розвитку, визначенню рівня воєнної загрози національній безпеці, виявленню можливих форм i способів ведення воєнних дій та засобів збройної боротьби.

Наступним етапом $є$ планування сценаріїв відповідно до тієї чи іншої прогнозованої воєнно-політичної і воєнностратегічної обстановки та очікуваних дій противника. Визначаються, крім іншого, цілі і завдання сил оборони, а також необхідні для їх виконання спроможності цих сил. Отримані дані $є$ вихідними для проведення оборонного планування.

Процес оборонного планування має включати планування розвитку: сил оборони та їх спроможностей; системи управління силами 
оборони; озброєння, військової та спеціальної техніки; військової інфраструктури; систем логістичного, медичного, кадрового та інших видів забезпечення.

Аналіз чинної системи оборонного планування в Україні та порівняння іiі 3 аналогічною системою в країнахчленах НАТО демонструє певні переваги останньої. Зокрема, це стосується структури та змістовності документів оборонного планування, що переконливо підводить до необхідності їх оптимізації в Україні.

Привертає увагу основоположний на сьогодні акт у ієрархії документів оборонного планування - Воєнна доктрина України. Після Стратегії національної безпеки, Воєнна доктрина, за характером своїх положень суттєво відмінний від стратегії документ, створюе певну дисгармонію. Тому місце Воєнної доктрини має зайняти Стратегія воєнної безпеки, як це практикується у країнах Заходу. Така Стратегія буде спрямована на досягнення визначених воєннополітичних цілей.

Вона має деталізувати ті положення Стратегії національної безпеки, які стосуються сфери воєнної безпеки, визначити напрями стримування та нейтралізації воєнних загроз, викласти основи розвитку сил оборони на сучасному етапі.

Головним розробником Стратегії воєнної безпеки повинно бути Міністерство оборони України, до основних завдань якого відноситься забезпечення формування та реалізація державної політики 3 питань національної безпеки у воєнній сфері, сфері оборони і військового будівництва у мирний час та особливий період щодо оборонного планування; військово-технічної політики у сфері оборони; військової кадрової політики.

3 урахуванням такої трактовки місця $\mathrm{i}$ ролі Стратегії воєнної безпеки вона повинна бути документом Президента України, який відповідно до конституційних повноважень “...здійснює керівництво у сферах національної безпеки та оборони держави”.

Найбільш доцільно у Стратегії воєнної безпеки України викласти наступні питання: оцінка воєнно-політичної і воєнностратегічної обстановки навколо України, визначення рівня воєнних загроз; можливий характер воєнного конфлікту як міждержавного, так і внутрішнього; концепція оборони держави в сучасних умовах; комплексне застосування державних ресурсів (політичних, економічних, військових, інформаційних тощо) в інтересах оборони; цілі і завдання сил оборони; основні напрями розвитку сил оборони; завдання сил оборони у зміцненні міжнародного миру i безпеки під егідою міжнародних організацій 3 питань безпеки; забезпечення реалізації Стратегії; основні завдання оборонного планування тощо.

Викладені питання ніяким чином не слід сприймати як пропозицію певної constant щодо структури Стратегії. В залежності від особливостей воєнних загроз, стану сил оборони та низки інших чинників вона може мати різні варіації.

Схемою перспективного оборонного планування (рис.1) передбачається розроблення цільового пакету спроможностей сил оборони, як додаток до Стратегії воєнної безпеки, який доцільно виконувати у форматі не деталізованого плану або дорожньої карти досягнення цілей розвитку сил оборони. Дане питання заслуговує на увагу i потребує подальшого вивчення.

Важлива роль в організації оборонного планування належить Міністерству оборони України і особисто Міністру.

Як керівник оборонного відомства він, за погодженням із Головнокомандувачем Збройних Сил України, Міністром внутрішніх справ України, іншими керівниками, у підпорядкуванні яких знаходяться складові сил оборони, видає наказ Міністерства оборони щодо засад організації планування розвитку сил оборони, де визначає: кількісні і якісні показники для кожної складової сил оборони; порядок реалізації спільних стратегічних цілей оборонної реформи; організацію спільної підготовки сил оборони тощо. Зазначений наказ Міністерства оборони України дозволить скоординувати оборонне планування в усіх органах управління сил оборони і визначити оптимальні шляхи реалізації завдань, визначених Президентом України. Результати цього планування відображаються у програмах розвитку Збройних Сил України, програмах розвитку інших військових формувань та правоохоронних органів (в окремих розділах “сили оборони”), а також в державних цільових оборонних програмах.

У свою чергу, Головнокомандувач Збройних Сил України має організувати розроблення та подання командувачами видів, окремих родів військ (сил) Збройних Сил України на затвердження Міністру оборони України плани (програми) розвитку підпорядкованих їм військ (сил).

У ході стратегічного (оперативного) планування застосування сил оборони визначаються відповідні сценарії в умовах тієї 
чи іншої прогнозованої воєнно-політичної і воєнно-стратегічної обстановки та очікуваних дій противника. Крім іншого визначаються цілі і завдання сил оборони, а також необхідні для їх виконання спроможності цих сил. Отримані дані є вихідними для проведення оборонного планування.

Організація та здійснення стратегічного (оперативного) планування застосування сил оборони визначається Доктриною застосування сил оборони.

Процеси оборонного планування має циклічний характер.

Довгостроковий цикл оборонного планування здійснюється за результатами оборонного огляду і завершується прийняттям звітних інформаційно-аналітичних матеріалів та затвердження стратегічних довгострокових документів оборонного планування.

П’ятирічний циклл оборонного планування проводиться не рідше чим один раз у п'ять років. У ході п'ятирічного циклу здійснюється середньострокове оборонне планування розвитку сил оборони та прийняття відповідних програмних і планових документів.

Річний циикл оборонного планування проводиться у рік, що передує року на який планується проведення відповідних заходів. У ході цього циклу здійснюється короткострокове планування, а його заходи узгоджуються 3 заходами бюджетного планування в державі.

У залежності від обставин (економічна або політична криза тощо) та при необхідності (наприклад - рішення Президента України) той чи інший цикл планування може розпочинатися достроково (до часу завершення раніше прийнятих програм (планів)) або змінюватися його плановий період (наприклад - замість п’яти років планується на чотири).

Але, за будь-яких обставин головною вихідною позицією оборонного планування має залишитися оборонний огляд, який, як правило, проводиться в рамках комплексного огляду сектору безпеки і оборони або окремо.

Враховуючи важливість оборонного огляду i високий рівень його учасників, рішення про проведення цього огляду має прийматися Радою національної безпеки i оборони України, яким визначається головна мета та основні завдання оборонного огляду, відповідальні виконавці та терміни надання звітів про його результати.

$\begin{array}{lrr}\text { Результати } & \text { оборонного огляду } \\ \end{array}$
України у звітних інформаційно-аналітичних матеріалах, які покладаються в основу розроблення стратегічних документів оборонного планування.

Таким чином, реалізуючи запропоновану логічну послідовність проведення процедур оборонного планування ми можемо уяснити перелік організаційних, аналітичних, виконавчих та забезпечуючих заходів процесу оборонного планування, а також чітко окреслити його підсумкові документи.

\section{Висновки.}

1. Оборонне планування доцільно розглядати як складову частину планування у сфері безпеки i оборони України, яке здійснюється 3 метою забезпечення іï обороноздатності шляхом визначення пріоритетів і напрямів розвитку сил оборони, озброєння і військової техніки, інфраструктури, системи підготовки військ (сил) тощо 3 урахуванням фінансово-економічних можливостей держави. При цьому, оборонне планування має бути максимально інтегрованим в державну систему стратегічного планування соціального i економічного розвитку України.

2. Ефективне використання ресурсів, у першу чергу фінансових, налагодження процесу оцінки їх використання за критерієм “вартість-ефективність” слід вважати одним із пріоритетних напрямків досліджень, наукового аналізу та діяльності органів військового управління.

3. Сталий розвиток сил оборони може бути забезпечений на основі запропонованої перспективної системи оборонного планування, яка адаптована до стандартів НАТО та враховує вітчизняний досвід. Вихідні документи цієї системи планування повинні мати більшу практичну направленість і бути орієнтованими на кінцевий результат щодо забезпечення обороноздатності держави.

4. Нагальною потребою $є$ продовження практики проведення оборонних оглядів в рамках комплексних оглядів сектору безпеки i оборони, а за необхідності - окремих оборонних оглядів відповідно до запропонованих циклів оборонного планування. При цьому доцільно широко залучати недержавні організації, науководослідні установи, а також вітчизняних та іноземних експертів, які опікуються питаннями оборони. В рамках стратегічних комунікацій корисно використовувати засоби масової інформації. Ключова роль у процесі оборонного планування має бути відведена узагальнюються Міністерством оборони 
Комітету реформ Міністерства оборони та Збройних Сил України.

\section{СПИСОК ВИКОРИСТАНОЇ ЛІТЕРАТУРИ}

1. Закон України Про організацію оборонного планування. (Відомості Верховної Ради України (ВВР), 2005, N 4, ст.97), [Електронний ресурс] Режим доступу:

zakon.rada.gov.ua/laws/show/2198-15

2. Закон України «Про центральні органи виконавчої влади». [Електронний ресурс] Режим доступу: http://zakon2.rada.gov.ua/laws/ show/3166-17.
3. Воєнної доктрини України. [Електронний ресурс]. - Режим доступу: http://www.president. gov. ua/documents / 5552015-19443.

4. Стратегічний оборонний бюлетень України. [Електронний ресурс]. - Режим доступу: http:// www. president.gov.ua/documents/2402016-20137.
6. Романченко I. C., Богданович В. Ю., Дєнєжкін М. М. Крикун П. М. “Стан і перспективи розвитку системи оборонного планування”, Наука і оборона № $1.2017 \mathrm{p}$.

7. "Is it Time to Bring Back Threat-Based Planning?", Major Tony Balaseviciucs, The Makenzie Institute (Canada), Security Matters, Spring 2016; CapabilityBased Planning and the Death of Military Strategy, Colonel Michael W. Pietrucha, U.S. Naval Institute, August 5, 2015.

Стаття надійшла до редакції 04.08.1017

\section{Крикун П.Н. ${ }^{1}$;}

Павленко В.И.';

Полякова Е. В. ${ }^{2}$;

Кравчук В.В.

1 - Национальный институт стратегических исследований, Киев;

2 - Центр военно-стратегических исследований Национального университета обороны Украины имени Ивана Черняховского, Киев;

3 - Департамент военной политики, стратегического планирования и международного сотрудничества Министерства оборони Украины, Киев

Развитие оборонного планирования как составной национальной системы планирования в сфере безопасности и обороны при условии сближения к процедурам и стандартам НАТО

Резюме. Проведен анализ состояния и требований к отечественной системе оборонного планирования в условиях широкого спектра современных военных угроз и перспектив развития в соответствии с принципами и стандартами НАТО.

Ключевые слова: оборонное планирование, военные угрозы, военная безопасность, оборона государства, силы обороны, оборонный обзор, стратегическое планирование применения сил обороны, бюджетное планирование, способности сил обороны, Стратегия военной безопасности, циклы оборонного планирования, стандарты НАТО.

\section{P. Krykun ${ }^{1}$; \\ V. Pavlenko ; \\ E. Polyakova ${ }^{2}$ \\ V. Kravchuk ${ }^{3}$}

${ }^{1}$ - National Institute for Strategic Studies, Kiev;

${ }^{2}$ - Center for Military and Strategic Studies of the National Defence University of Ukraine named after Ivan Chernyhovsky, Kyiv;

${ }^{3}$ - Department of Military Policy, Strategic Planning and Inter-National Cooperation of the Ministry of Defense of Ukraine, Kiev

Development of defense planning as an integral national planning system in the sphere of security and defense for the conditions of rapprochement with NATO standards

Resume. The analysis of the state and requirements for the national defense planning system was carried out in the context of a wide range of modern military threats and development prospects in accordance with NATO principles and standards.

Keywords: deefense planning, military threats, military security, the defense of the state, defense forces, defense review, strategic planning of the use of defense forces, budget planning, defense capabilities, the military security strategy, the defense planning cycles, NATO standards. 